\title{
Escapism in Sam Shepard's The Buried Child
}

Irwan Sumarsono

irwan@pens.ac.id

\author{
Radina Anggun Nurisma \\ dina@pens.ac.id
}

Imam Dui Agusalim

Imam_dui@pens.ac.id

Eny Kusumawati

eny_k@pens.ac.id

Elizabeth Anggraeni Amalo

lisa@pens.ac.id

Politeknik Elektronika Negeri Surabaya

\begin{abstract}
This study is a qualitative research that was conducted to analyze the escapism of Dodge's in Sam Shepard's The Buried Child. The writer uses the psychological approach to analyze the escapism of the main character, Dodge. Data were collected from some sources. The main source of the data was taken from the work entitled The Buried Child, while the supporting sources were derived from books, journals and from the internet. The collected data were analyzed using the descriptive analytic techniques. The study focused on the factors behind the reasons why Dodge withdraws himself from his real world, what makes him an escapist that makes the disintegration of his family. Dodge's escapism takes place since he is betrayed by his wife and his own son who have an incestuous relationship that make them have a baby, and to cover this sin, the baby was buried. The betrayal of his wife and son makes him escapes from the reality into alcohol and makes him does not have any respect and love to his family.
\end{abstract}

Keywords: Escapism; Buried Child; Depression; Incestuous

\section{INTRODUCTION}

Sam Shepard was born in Illinois, November 5, 1943. His father was an army and had to leave the family for war. Having a father as an army made Sam Shepard and his family had to move from one base to another base. When his father was away for a war, his mother was the only one who had to take care the family and faced the family problems. Sam's father was an alcoholic who left his family. The failure of his own family inspired him in writing his works. 
Shepard's plays display an unideal family in which most of the members of the family lack of love, attention, care, and sense of belonging. Abdelsemie stated that Shepard plays depict the American family not as a heaven of protection against a hostile world, but as all life; that is violent and contradictory. Its members rather than enjoying the surroundings of love, security, ease of soul and satisfaction; they experience familial starvation, lacking sense of belonging and assertion (Abdelsamie, 2013).

Sam Shepard started his playwright career in Broadway in 1960s. Shepard was one of the United States' most productive playwrights. During his life, he managed to write about 58 plays. He also wrote several books of short stories, essays, and memoirs. He was not only an author but also an actor, a playwright, a screenwriter, and director. He won some Obie Awards and a Pulitzer Prize for Drama in 1976 for his play Buried Child. His most sparkling works, such as the Pulitzer prize-winning Buried Child (1978), True West (1980) and Fool for Love (1983), established him as one of the visionaries of US theatre and created a fresh vernacular for exploring the unequal in American life between myth and reality, past and present, fathers and sons (Gilbey, 2017).

Buried Child is one of Sam Shepard's masterpiece. It belongs to the family drama which is considered as the second play of his trilogy; the first was Curse of Starving Class in 1977, Buried Child in 1978 and the last one is True West in 1980, which deal with the infanticide and incest themes. Undoubtedly, Buried Child has psychological implications that study the effect of the secret on the consolidation of the family (Hammood, et.al, 2020). Buried Child is about the corruption of the American family where the guilt and the secret of the family are hidden from the society for a long time. The buried chil is the hidden guilt and secret of this family since the child is regarded as the result of the incestuous relationship between Halie and Tilden. Shepard portrays 'a possible world' of a dysfunctional American family parodically depicted as a house of the dead rather than a home (Amani, Pirnajmuddin and Marandi, 2017).

Buried Child is a three-act drama that represents the American family with its problem in the forms of family disintegration caused by the disappointment and disillusionment of the members of the family. The disappointment of the members of the family is caused by the failures of the members of the family in managing their social roles and their failure in respecting the marriage institution. Monogamy is very essential in the family life, while adultery is a very serious sin since it is a kind of betrayal of love and marriage institution. Marriage for the American family at that time was very sacred. When a man and a woman were united in a marriage institution, they had to love each other and continued their life together whatever happened with them. They could not be separated by whatever conditions and situations. The ones that were united could not be separated.

Family is the smallest social group that consists of at least a husband and a wife. Both the husband and wife have their own functions and roles, both in the family 
and in the society. Bible states that the responsibility of leadership in marriage falls on the husband's shoulders, husband is the head of the wife. A good husband loves his wife unconditionally. He should respect, affirm and love her at all times. Sacrificial action is an integral part of the husband's role. In marriage, husband has to ensure that the wife's material, emotional, and spiritual needs are met (Tucker, 2015). In American family, the male is considered the breadwinner, the caretaker and the main source of income for the family and the female (wife) is considered the back bone and responsible for maintenance of family. But in this Buried Child spiritual immorality has left them opposite of it (Mir, D.A., Vijaya, R, 2017). There is a blood bond between each member of the family. A person is considered as a member of a family when he or she has blood relationship with the other members of the family, so biological and social relationship in the family is very necessary. Membership of a family can be derived through marriage and adoption. Family is one of the sources of happiness. People are very proud of their family. The family unity and integration are what people dream to have. When they can have an integrated and united family, they can run their life happily.

Buried Child is about an American family consists of three generations, parents, children and grandchildren. Each family member in the play suffers a collective unspeakable trauma and is damaged in some way, implying that a part of the family is buried underground (Zhang, 2020). Dodge, the father is an alcoholic and spends most of his time laying on his sofa and watches television. His bad habits drinking alcohol makes him have a serious cough. He is about 70 years old. He used to be a wealthy farmer who has a prosperous farm that is now abundance and rundown. He seems so disappointed with both his sons and his wife. His disappointment is caused by his sons' failures in their lives and the betrayal of his wife, Halie and his son, Tilden who had a forbidden love relationship, an adultery, or precisely an incestuous relationship that make Halie get pregnant and has a baby. As the title of the play, Buried Child, the family has a secret that all the members of the family have covered or hidden from the other people. This disappointment makes Dodge withdraws himself from his real world to his own world, the world of alcohol. He escapes from the reality that he fails in building an ideal family. He fails in educating both his wife and sons, especially Tilden to have the moral and religious values. His wife's incestuous relationship with Tilden is a serious sin of the family that makes him distressed. He becomes sickly father and husband, lacks of love, care and respect to his family. He who used to be a wealthy farmer, now he becomes poor, sick and alcoholic.

This study will examine the escapism of the central character, Dodge, especially the factors that make him have an escapism from the real life and the effects of his escapism. The study uses the psychological point of view to examine the stated problems above. The word escapism is derived from the French-language escapade, which means evasion. The word escapism is defined in Cambridge Advanced Learner's Dictionary as an 'action to avoid reality by imagining exciting but unrealistic actions'. Escapism is also defined as 'a tendency to seek or practice in this field or to distract from what usually has to be endured'. The people who 
experiences it is called as an escapist. Stereotypically escapists are people who are depressed and failed to face their life problems. They run away from the real world to the world on illusion. They try to find a solution of their problems. Some people succeed in finding good solution, but some others fail. The ones who fail to find a good solution tend to withdraw themselves from the real world to the world of imagination or illusion. The escapists tend to avoid the confrontation with the real world. They run to their world of illusion by doing new activities that they think by doing so they can forget their problems.

Escapism is the tendency to escape from the real world to someone's own world to get the safety and comfort. People who experience an escapism will live in the world of fantasy. Escapism can be either positive or negative, depends on how the individual reacts to the reality, how the individual uses the escapist strategy in facing his or her problems. Oxford English dictionary defines escapism as the tendency to seek distraction and relief from unpleasant realities, especially by seeking entertainment or engaging in fantasy.

Evans in Igorevna states that escapism is a kind of activity occurring because of the current conditions of our media society. He classifies escapism into four different types, namely avoiding, passive, active and extreme escapism. Avoiding is running from reality and real life difficulties. While passive escapism includes activities when person does not have to make any efforts. Active escapism is assumed a change of activity, from main activity to the alternative one. And the last type is the extreme escapism refers to the activities which are potentially dangerous such as the use of drugs and alcohol (Igorevma, 2015).

Seryczyńska refers escapism as a form of avoiding confrontation with reality, which is represented by the proverbial behavior of an ostrich hiding its head in the sand (Seryczyńska, 2019). Escapism is seen as something sought by those dissatisfied with the trajectory of their lives, or unwilling "to connect meaningfully with the world. Therefore, escapists are often stereotyped as depressed individuals who rely on mental diversion as a means of removing themselves from the banal aspects of daily life (Vega, 2014). Dodge as the escapist in the drama Buried Child is a stereotyped of a depressed husband who avoids the reality and withdraws himself to his own world of being a sick alcoholic husband.

\section{LITERATURE REVIEW}

\section{Previous Related Study}

Some writers have studied about Buried Child in different points of view and different perspectives. In analyzing the Buried Child, the writers also read the studies conducted by the other writers.

Zuhriyah in her paper entitled Conflict and Consensus in America Described in Buried Child Drama stated that the family in Buried Child is destroyed and 
disturbed by the deviations in the family and the outside of the family, Every individual in the family has her/his role in destroying the family, and on the other hand the social power also takes part in the family destruction (Zuhriyah, 2006, 40).

Purwanto in his paper entitled The Significance of Dodge's Schizophrenia towards the Conflict in Shepard's Buried Child states that the conflict in the family gets worse caused by Dodge's schizophrenia. The schizophrenia attacks his mind and changes his behaviour. Dodge's schizophrenia has a contribution for the conflict in the family (Purwanto, 2011, 71).

\section{Escapism}

Escapism is defined as an action to avoid reality by imagining exciting but unrealistic actions. It can also be defined as a tendency to seek or practice in this field or to distract from what usually has to be endured. People who experiences the escapism are people who are depressed and failed to face their life problems.

\section{Incestuos}

Incestuos relationship is a forbidden relation between a member of a family with another member. An incestuous relationship involves sexual intercourse between two members of the same family, for example a father and daughter, or a brother and sister. Incest - is associated with particularly severe psychological symptoms and physical injuries such as having a feeling of depressed, damaged and psychologically injured. Additional symptoms include low self-esteem, selfloathing, somatization, low self-efficacy, pervasive interpersonal difficulties and feelings of contamination, worthlessness, shame and helplessness (Lawson, 2018)..

\section{METHOD}

\section{Design and Samples}

The research method used by the writer in this study is the qualitative method which was based on library research. The focus of the study is to analyze the escapism of the character, Dodge in Sam Shepard's Buried Child. The writer also uses the psychological approach to get a better understanding of the problem. The focus of the analysis will be on the backgrounds that makes the character has a certain behavior, especially on the escapism of Dodge's and its effects to the family life.

\section{Instrument and Procedure}

The writer has two kinds of data, main data that is derived totally from Sam Shepard's Buried Child, and the supporting data derived from any source such books, journals of literature, articles in the internet and some related sources. The collected data then summarized and interpreted to answer the problems of the study. The writer uses the descriptive method to describe the data that have been collected. 
As the center of this study is the escapism, the writer uses the theory of psychology to analyze the study. Psychology is used to help the writer to understand the characters in the Buried Child. Since literature is a product of human mind, so to understand it we need to use psychology. Therefore, psychological theories can be used to help us to understand fictions. By using the psychological theories, the writer tries to find out the facts about Dodge's escapism, the factors and the destructive effects resulted by this escapism.

\section{Data Analysis}

The writer uses the descriptive research to analyze the data. The aim of the research is to describe the problems that are studied. In this study the descriptive research is used to describe the background of the character's escapism from his real world to the world of his own, and the effects of his escapism to the character's life and his family.

\section{RESULT AND DISUSSION}

\section{Dodge's Relationship with Halie}

Marriage is a form of a lifelong companion between a husband and a wife. Both husband and wife have the equal rights, status and obligation. An ideal family needs a cooperation between husband and wife in working a managing the household affairs. They should encourage and help each other in any business and problem. An ideal family will take care to each other. They have the same responsibility in taking care the children and their education. Husband and wife should be able to increase their love and mutual respect to make their marriage an ideal one.

Husband and wife must have a good communication. Both of them cannot take each other for granted. They have to take each other seriously any time, whether they talk about a small issue or the big one. An ideal family should have quality time with each other. Both husband and wife must be a good listener. They have to listen to each other. When a husband or a wife listen to his or her spouse, he or she will feel that she or he is appreciated. Expressing respect and gratitude is very important. By expressing the gratitude, a spouse can let his wife or her husband know that he or she is appreciated.

Honesty and openness are very important in a husband and wife relationship. There should be no secret between them. When there is a problem or information that needs to be told to the partner, they have to sit together and talk about it. They cannot hide the problem or the information from each other. They have to share their dreams, hopes and fears. Being honest and opened will build a strong love relationship. An ideal family has no lie. Any lie can cause a serious problem that will lead to family disintegration. 
The relationship of Dodge and Halie in Sam Shepard's Buried Child is very far from the ideal family that the society hopes to have. Dodge and Halie have a serious problem in their relationship as husband and wife. From the way to talk to each other we can see that they do not have any respect to each other. Both Dodge and Halie speak loudly and sometimes they have to scream to each other. Even we see that Dodge like mimicking her. Neither Dodge nor Halie is not a good listener. Dodge does not care with what Halie says and does. He enjoys his time watching television, laying on his sofa, drinking whiskey and smoking cigarettes. Dodge as the head of family feels that he does not have any dominant control in the family. He cannot stop his wife from having lunch with another man. It seems that it is his wife now that holds the dominant control in the family. Halie is the one who rules the family. It is Halie who controls Dodge's life by giving orders on what he can do and what he cannot do. It is Halie who orders him when he has to eat his pills and stop watching television, drinking and smoking. Dodge as a man has lost his masculinity.

What makes their relationship as husband and wife far from the ideal family is there are some lies between them. Halie has betrayed Dodge for several time. She has some extra marital relationships. She is not a loyal wife both in the past and in the present. In the present she has an adultery with a clergyman from a church, Father Dewis that she brings home one day. And she has an incestuous relationship with her own son, Tilden, and she had a baby with him. An adultery is considered a serious sin, while an incestuous relationship is a more serious sin. This reality makes the disintegration of the family. Dodge loses his respect to his wife. They cannot sit together and listen to their hopes, dreams and problems. How a husband can listen to a wife if she has betrayed him. This reality has driven Dodge away from his real world. He was used to be a successful farmer before he found out his wife had a baby with his own son. Now Dodge is a sick old man who can only lay on his sofa watching television, drinking whiskey and smoking cigarettes. All what he does is his escape mechanism from the real world.

\section{Dodge's Relationship with His Children}

Dodge's relationship with his children is not an ideal one. There is a serious problem among them. Dodge was used to be a responsible father for his children. He planted corns and became a wealthy farmer who could earn the family living. But Dodge changes his identity from being a responsible man or father becomes a drunker who is immovable and lays on his sofa watching horse racing on television.

Dodge has three children, Tilden, Ansel and Badley. With Tilden, Dodge has a very complicated relationship since he finds out the incest Tilden committed with his own mother, Halie. The incest relationship between his wife and Tilden has hurt him very much and changed him forever. Tilden is the oldest son and Dodge wanted him to be the one who will continue the generation, but Tilden has disappointed him very much. Tilden who left home to gain his successful life has come home as a loser. He failed to make Dodge proud as a father. The worst thing is Dodge found 
out that Tilden committed an adultery, an incest with his own mother, Halie. To hide the sin, Dodge killed the baby of Tilden and Halie's.

Dodge also has a bad relationship with Bradley. It can be seen from the way how Bradley cuts his hair and how Dodge dislikes Bradley's way to cut the hair.

"You tell Bradley that if he shows up here with those clippers, I'll kill him!" (Shepard, 1976)

Dodge as a father has lost his dominant control over his children. His sons have no respect on him. The only one that Dodge can hope to continue the next generation is Vince, his grandson, the son of Tilden, although in the beginning Dodge does not want to recognize him.

\section{Dodge's Escapism}

Dodge, the central character of the play, is described as an old and sick husband and a grandfather of 70s years of age who always lays on his sofa in front of his television watching horse race and covers his body with his blanket. He has a terrible cough but he does not want to stop drinking alcohol and smoking cigarettes. She does not listen to his wife, Halie, who always forbids him from smoking and drinking whiskey. It seems that Dodge does not care with his illness. Nobody can stop him from his bad habits.

Dodge is described as a rough and impolite person. He always treats his wife and other people roughly and impolitely. He always speaks loudly since his wife, Halie, is a little deaf. He does not like to be interrupted by other people when he is doing what he likes to do. Even he likes to use impolite word like stupid when he talks to other people.

Gradually the form of Dodge is made out, sitting on the couch, facing the TV, the blue light flickering on his face. He wears a well-worn T-shirt, suspenders, khaki work pants, and brown slippers. He's covered himself in an old brown blanket. He's very thin and sickly looking, in his late seventies. He just stares at the TV. (Shepard, 1976, 1).

Dodge used to be a rich farmer who had a prosperous farm. He had a beautiful and happy life with his family as all the American families dream. He lived happily with his wife, Halie and his three sons. Halie is described as a hypocrite who ignores the bleak circumstances around her by indulging in a mix of nostalgia, religion, and extra-marital sex. She cites citing religion as her guide, and yet her own actions are wholly self-interested. She has an extra marital relationship with Father Dewis. She also attempts to cover her the secret that she has an incestuous relationship with her own son, Tilden.

Dodge's escapism is caused by his depression after he finds out the reality that his eldest son, Tilden, who he wanted to continue his generation, the one that he puts his dreams on came home as a loser. He also finds out that his second son, Bradley 
cannot be success since he lost his leg. And the worst thing that happens in the family is the reality that his eldest son, Tilden had an incest relationship with his own mother or Dodge's wife, Halie.

The incestuous relationship of Tilden and his own mother changes everything in the family. Dodge gets depressed of being betrayed by his wife and his son. The incestuous relationship makes Halie get pregnant and had a baby. Dodge knows that Tilden is the father of the baby since Dodge and his wife have never slept for several years. He does not like and want the baby grow and live together with the whole family. He killed the baby and buried it somewhere in the farm and nobody knows about. The whole family keeps the secret for more than thirty years.

"DODGE: Tilden was the one who knew. Better than any of us. He'd walk for miles with that kid in his arms. Halie let him take it. All night sometimes. He'd walk all night out there in the pasture with it. Talking to it. Singing to it. Used to hear him........nothing. Everything was canceled out by this one mistake. His one weakness. (Shepard, 1976, 58).

Dodge gets distressed very much after he knows that Halie and Tilden betrayed him. The adultery and incestuous relationship that have made Halie have a baby is the sin of the family. Dodge is very disappointed and depressed. He is so angry, mad, guilty, confused and ashamed to face the reality. This condition makes him withdraw himself from the real world to his own world. It is the starting time when Dodge has his escapism and becomes an escapist. He stopped growing corns in his farm. He starts to destroy not only his own life but also his family. He runs away from the real world into the world of alcohol and television.

He gets more depressed when he has to face the reality that his wife, Halie also has an extra marital relationship with Father Dewis. Dodge loses his masculinity both as a man and a father. He runs to alcohol, cigarettes, and horse racing on television. He becomes a sick person who just lays down on his sofa. He knows that whiskey and cigarettes have ruined both his life and his health, but he does not care about it. He stops growing corn that makes the field is abandoned.

"DODGE: There hasn't been corn out there since about nineteen thirty-five!

That's the last time I planted corn out there." (Shepard, 1976,14)

The sin that Halie and Tilden committed has driven Dodge into a frustrated both as a husband and a father. This is the factor that causes Dodge withdraws himself from his real world and becomes an escapist. His being an escapist has ruined his life and caused the disintegration of the family. The ideal family will always have respect among any member of the family, but in Dodge's family, each member of the family lacks of respect to each other. The role of the father and the mother or the role of the husband and wife in Dodge's family is not fulfilled by both of them. Dodge, as the husband and the father in the family, fails to be a good leader. In the ideal family a good husband loves his wife unconditionally. He should respect, affirm and love her at all times, but in Dodge's family, it cannot be fulfilled. Dodge does not have any love anymore for his wife. He has to stay with her at the rest of his life because 
in his believe that someone who is united in marriage cannot be separated. Dodge loses his respect to his wife. Sacrificial action is an integral part of the husband's role. In Marriage, husband has to ensure that the wife's material, emotional, and spiritual needs are met, but how he can fulfil it if he does not love and care with the wife anymore. His being depressed makes him deny Bradley as his own son, and he even does not care and not happy when Vince, the son of Tilden's, comes home with his girlfriend. He does not recognize him and does not want to tell Vince what has really happened with the family. An ideal grandfather will be very happy to see his grandson who has not seen for a long time, but it is no Dodge. Dodge is not happy and surprised when Vince tells him that he is Tilden's son, which means he is his grandson.

His escapism has driven his family into the disintegration that make the members of the family cannot live like the ideal family. There is no respect, love, care and affection among the members of the family. Dodge's escapism had made him sick. His escape mechanism to smoking cigarettes and drinking whiskey makes Dodge not be able to stop from his bad habits and makes him get a terrible cough and sick. But the most destructive one is his inability to face the reality that the wife who he loved very much has betrayed him not with the other person, but with his own son. Although he tries to keep it as a secret, and not to tell anybody, but he finally cannot bear it all. He has to disclose the reality, although it makes Halie does not like to hear it because she does not want Dodge to uncover the secret that the family has kept for a long time. Dodge does it since he is unable to live with the sin any longer, he admits all the details of incest and murder. The one that causes him depressed and run away from the reality.

'DODGE: well even if ya'don't I'm gonna' tell ya'. (pause) alie had this kid. This baby boy. She had it. I let her have it on her own. All other boys I had the best doctors, best nurses, everything. This one I let her have by herself. This one hurt real bad. Almost killed her, but she had it anyway. It lived,see. It lived. It wanted to grow up in this family. It wanted to be just like us.It wanted to be part of us. It wanted to pretend that I was its father. She wanted me to believe in it. Even when everyone around us knew. Everyone. All our boys knew. Tilden knew." "HALIE: YOU SHUT UP! Bradley, make him shut up!"

"DODGE: Tilden was the one who knew. Better than any of us. He'd walk for miles with that kid in his arms. Halie let him take it. All night sometimes. He'd walk all night out there in the pasture with it. Talkin to it. Singin to it. Used to hear him........nothin. Everything was cancelled out by this one mistake. His one weakness.

"SHELLY: so you killed him?"

"DODGE: I killed it. I drowned it. Just like the runt of a litter. Just drowned it." (Shepard, 1976, 58)

Haunted by the feeling of guilty after he killed the baby of Tilden and Halie and kept the secret for a long time makes Dodge has to uncover the secret. He makes a confession in front of Shelly, Vince's girlfriend, and the other members of the family that he killed the baby, and he says that everyone in the family knows that 
Halie and Tilden have an incestuous relationship and had a baby that Dodge killed since he does not want to pretend of being its father.

\section{CONCLUSION}

Dodge's depression is caused by the reality that he has been betrayed by both his wife and his son. His wife hides a secret that behind him, she has an incest with her own son, Tilden. The forbidden relationship made her get pregnant and had a baby. Being humiliated both as a husband and a father makes Dodge angry and killed the baby. The incestuous relationship of Tilden and Halie makes Dodge lose his masculinity both as a man as a father. This reality causes him in a serious depression. His being depressed makes him experience an escapism. He withdraws himself from his real world into the world of alcohol and cigarettes.

Escapism has made Dodge withdraw himself from the world of reality to his own world to get safety and comfort. By being in his own world he can get his safety and comfort, although the safety and the comfort that he gets are not the real ones, but the fake ones. Dodge who used to be a wealthy farmer stops growing corns that makes his farm abandoned. He becomes addicted to alcohol and cigarettes. His escapism makes him a sick person who cannot do any job and has to lay down on his sofa almost all his time, drinking alcohol and smoking cigarettes. His escapism is caused by the betrayal of his wife and son, Halie and Tilden, who have incestuous relationship until his wife got pregnant and had a baby. His escapism has driven the family into disintegration, in which each member of the family has lacked respect to each other. The escapism has made the family far from the criteria of an ideal family. There is no love, care, and affection among the members of the family. His being guilty of killing and burying the baby of Halie and Tilden makes him depressed for a long time. The secret that the whole family keeps covered for a long time, finally has to be uncovered by Dodge because of his guilty feeling. Dodge's escapism has destroyed his life and his family. He reacts to his depression negatively by escaping his real world to his world of drinking, smoking, watching horse race on television and by bearing his anger to his family.

\section{REFERENCES}

Abdelsamie, Adel. M. (2013). The Ideal of the Family In Sam Shepard's Buried Child. Bulletin of The Faculty of Arts, Vol. 35 , Oct. 2013

Amani, O., Pirnajmuddin, H., Marandi, S.M. (2017). Sam Shepard and the "Familial Maze": Possible Worlds Theory in Buried Child. GEMA Online ${ }^{\circledR}$ Journal of Language Studies Volume 17(2), May 2017 http://doi.org/10.17576/gema-2017-1702-05

Gilbey, Ryan. (2017) Sam Shepard Obituary; Playwright, actor and director who exposed the gap between myth and reality in American life https://www.theguardian.com/stage/2017/aug/01/sam-shepard-obituary

Hammood, N.A., Mahmood, S.D., Hashim, M.R. (2020). The Offstage Character in Modern American Drama: Sam Shepard's Buried Child. International 
Journal of Applied Linguistics \& English Literature E-ISSN: 2200-3592 \& P-ISSN: 2200-3452 www.ijalel.aiac.org.au

Igorevna. O. (2015) Escapism: current studies and research prospects in contemporary psychology. Austrian Journal of Humanities and Social Sciences, Association for Advanced Studies and Higher Education GmbH. Vienna.

Lawson, David. M (2018). Understanding and treating survivors of incest. Accessed from https://ct.counseling.org/2018/03/understanding-treatingsurvivors-incest/

Mir, D.A.,Vijaya, R. (2017) Familial Disintegration: A Study of Sam Shepard's Buried Child. International Journal of Academic Research and Development.Volume 2; Issue 6; November 2017; Page No. 612615.www.academicsjournal.com

Purwanto, B.A., (2011). The Significance of Dodge's Schizophrenia towards the Conflict in Shepard's Buried Child. English Letters Study Programme Department of English Letters Faculty of Letters Sanata Darma University. Yogyakarta. Accessed from https://repository.usd.ac.id/26507/2/054214082_Full\%5B1\%5D.pdf

Seryczyńska, B (2019). Creative Escapism and the Camino de Santiago. International Journal of Religious Tourism and Pilgrimage ISSN : 2009 -7379 Available at: http://arrow.dit.ie/ijrtp/

Shepard, Sam. (1979). Buried Child. New York: Urizen Books.

Tucker, M. (2015).What is the Husband's and Wife's Role in a Biblical Marriage. Accessed from https://madaboutmarriage.com/2015/05/15/what-is-thehusbands-and-wifes-role-in-a-biblical-marriage/

Vega, I. (2014). Escapism in Dance and One Hundred Years of Solitude. Senior Seminar in Dance Fall. Accessed from file:///C:/Users/MuhammadSyarifuddinF/Downloads/vdocument.in_by-ivyvega.pdf

Zhang, F. (2020). What the Buried Child Stands for: A Thematic Study of Sam Shepard's Buried Child. English Language and Literature Studies; Vol. 10, No. 2 ISSN 1925-4768 E-ISSN 1925-4776 doi:10.5539/ells.v10n2p75

Zuhriyah (2006). Conflict and Consensus in America Described in Buried Child Drama. Department of English Letters, Faculty of Adab and Humanities Syarief Hidayatullah State Islamic University. Jakarta. Accessed from https://repository.uinjkt.ac.id/dspace/bitstream/123456789/11174/1/ZUHRI $\underline{\text { YAH-FAH.pdf }}$ 